\title{
Morphological and Stomatal Characteristics of Two Indonesian Local Orchids
}

\author{
Meutia Zahara ${ }^{*}$, Cho Cho Win ${ }^{2}$ \\ ${ }^{1}$ Department of Biology, Islamic Faculty, Muhammadiyah Aceh University, Banda Aceh 23245 Indonesia \\ ${ }^{2}$ National Project Coordinator, Farming System Sustainability Project-Myanmar, Nay Pyi Taw 15011, Myanmar \\ *Corresponding author: teeya_razali@yahoo.co.id
}

\section{ARTICLE HISTORY \\ Received: 11 August 2019 \\ Revised: 23 September 2019 \\ Accepted: 5 October 2019}

\section{KEYWORDS}

Local orchids,

Stomata,

Phalaenopsis amabilis $L$.

Dendrobium x Superbiens

\begin{abstract}
Orchids are very famous for their beautiful and long-lasting flowers and variety among the most diverse family of flowering plants in the world, comprising thousand species and hybrids and very attractive. The research aimed to determine the morphological features of two local orchids Phalaenopsis amabilis L. and Dendrobium x Superbiens and the stomatal characteristics of both orchids. Plants were the only living organisms that are able to convert light energy/sunlight into chemical energy, and stomata is an important part of plants for $\mathrm{CO} 2$ to enter the leaf and $\mathrm{H} 2 \mathrm{O}$ to be released during the photosynthetic reactions. The results showed that Phalenopsis amabilis L. was monopodial orchid and Dendrobium x Superbiensis a sympodial orchid. A qualitative descriptive research method used to describe and interpreted the type of stomata of Phalaenopsis amabilis L and Dendrobium sp. stomatal density were counted on adaxial and abaxial part of the leaf, and the highest stomatal density was obtained on the abaxial part of Dendrobium $x$ Superbiensleaf $290.81 \mathrm{~mm}-2$. The type of stomata was anomocytic for two local orchids.
\end{abstract}

This is an open access article under the CC-BY-SA license.

\section{INTRODUCTION}

Orchids are great ornamental plants with beautiful and long-lasting flowers and variety among the flowering plants family in the world. These ornamental plants comprise a thousand species and hybrids, very attractive to almost every individual (Agampodi and Jayawardena, 2009). Indonesia is home for nearly 5000 species of orchidaceae (Puspitaningtyas and Mursidawati, 1999); approximately 731 species are found in the java island, 231 types are stated endemic (Maniket al. 2017). Phalaenopsis orchid is well known as the most popular orchid genus in the industry of horticultural due to its colorful, large and durable flower (Kosiret al. 2004). Phalaenopsis amabilis L. Blume, commonly known as moth orchid, is one of the Indonesian native orchids that exhibits beautiful color, white color, and lost the lasting flower. This orchid has been designed as the Indonesian national flower (Semiarti, 2002). Dendrobium is one of the orchid genera that distributed widely from Southeast Asia to Australia, approximately 1.600 species (De et al. 2015), about 275 species found in Indonesia (Gandawidjaya and Sastrapradja, 1980). The diversity of orchids in Indonesia continues to decline due to deforestation, habitat destruction and excessive exploitation (Darmawati et al. 2018). Therefore, the preservation and inventory of orchid species need to be done in Indonesia (Lestari et al. 2013).
Plants are the only living organisms that are able to convert light energy/sunlight into chemical energy through the process called photosynthesis, carbon cycle, and water. The simple sugar is the product. Sugar or glucose is an essential building block for all living organisms and sources of energy (Robertson et al. 2006). Stomata are one important part of the plant, which is the way for $\mathrm{CO} 2$ to enter the leaf and $\mathrm{H} 2 \mathrm{O}$ to be released. In plants, photosynthesis strongly depends on the opening and closing of stomata, which mediated by guard cells. Stomata are adjustable pores that are abundantly found on the aerial organs of the higher plants. Stomata are mostly found on the adaxial and abaxial surface of the leaves, known as amphistomatous leaves. While some trees have stomata only on the lower surface, known as hypostomatous leaves whereas aquatic plants like lilies are found to have stomata pores on the upper surface called epistomatous leaves (Joshi, 2018). The research aims to determine the morphological features of two local orchids Phalaenopsis amabilis L. and Dendrobium x Superbiens and the stomatal characteristics of those two orchids.

\section{MATERIALS AND METHODS}

\subsection{Study Site}


The experiments were conducted in June 2019 at the laboratory of Biology Department, Islamic Faculty, Muhammadiyah Aceh University, Banda Aceh, Indonesia. The plant material was collected from an orchid garden in Banda Aceh.

\subsection{Stomatal type identification}

A qualitative descriptive research method was used to describe and interpret the type of stomata on the adaxial and abaxial leaf of Phalaenopsis amabilis $\mathrm{L}$ and Dendrobium x Superbiens, which was identified by using a light microscope at Biology Department, Islamic Faculty, Muhammadiyah Aceh University. Replica method was used to prepare the slide to observe the stomatal type, stomatal number, stomatal density and epidermal cell under the microscope. The steps as follows: (1) Cleaning the upper and lower surfaces of the leaves, (2) Applying the nail polish and leaving it for 10 minutes to be dried (3) dried spreads were attached with transparent tape and flattened, (4) the transparent tape was peeled and removed slowly from the leaves surfaces, then attached to the object-glass, (5) flattening and labeling with a description of the plant type, and (5) Observing Stomatal type by using a light microscope with same magnification (40x) (Haryanti, 2010).

\subsection{Stomatal density calculation}

Stomatal density calculation was done after the total number of stomata with three views (three repetitions) was counted for each species with the following formulas:

$$
\text { Stomatal density }=\frac{\text { Number of stomatal }}{\text { Field of view under microscope }}
$$

The number of stomata was calculated under a microscope with 10x magnifications, while the field of view calculated with the same formula with circle area formulas.

Field of view under microscope $=\pi \times r^{2}$.

Value of $\mathrm{r}=0.25 \mathrm{~mm}^{2}$ for $10 \mathrm{x}$ magnifications (Lestari, 2006).

\section{RESULTS AND DISCUSSION}

\subsection{Morphological features}

Phalaenopsis comprises over 60 native species all over the world, and it's very popular among the breeders and collectors, also high impact for economic values. This orchid is famous as moon orchid in Indonesia that has a high demand and be cultivated in various groups, mostly found in many tropical regions like Indonesia, Malaysia, the Philippines, Myanmar, and Thailand. Having a large size of the flower, elegant appearance, varies in flower color, long-lasting flower, and durable up to two months (Yuswanti et al. 2015). Phalaenopsis amabilis L. (Fig. 1A) is one of the most important type of local orchid especially in Indonesia and widely used as a mother plant for a new hybrid.

The root of Phalaenopsisamabilis L. has a pointed tip, rather sticky, soft and easy to be broken (Table 1). There are two types of Phalaenopsis roots; sticky root which function is to attach the stem to its position, and aerial roots which function is to absorb the nutrients (Rukmana, 2010). The stem is thick and protected by a wax layer to prevent excessive evaporation. The stem growth is monopodial and short which only has one stem and grows pointedly (Sitanggang dan Wagiman, 2007). This orchid doesn't have pseudobulbs, there are some aerial roots around the stem. The leaf is thick, the wide and length vary from one to each other. The number of the leaves about 3-8 each plant, elliptical shape with a wide tip, 15 to $30 \mathrm{~cm}$ in length, 8 to $15 \mathrm{~cm}$ in width, the color is dark green, smooth and fleshy because it contains chlorophyll and as water storage. The flower is white and composed. The flower stalk about $10-15 \mathrm{~cm}$ in length, and the number varies depending on the types and species. Comprising of three calyces with lancet-shaped, three corollas in a circular shape, and one gynostemium (Iswanto, 2005).

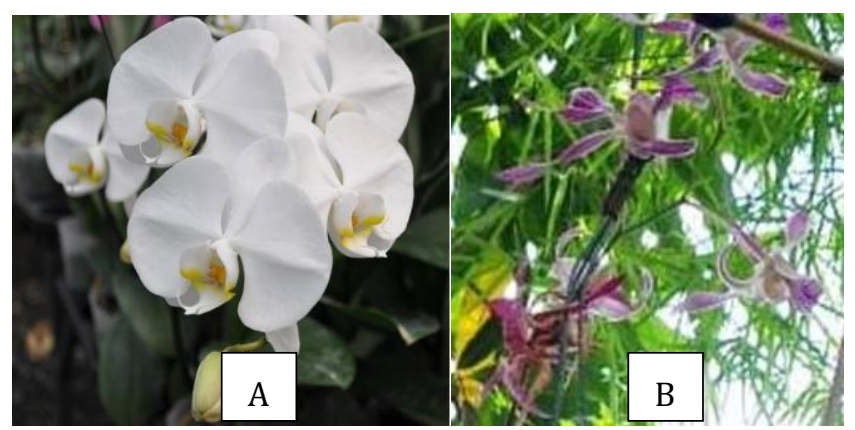

Figure 1. The flower of (A). Phalaenopsis amabilis L. (B).

Dendrobium x Superbiens

Dendrobium $x$ Superbiens(Fig. 1B) (Table 1) is an Indonesian local orchid species that can be found in wildlife. This orchid belongs to Orchidaceae family and has curly pinks orchid; the leaf is dark green with 10-18 $\mathrm{cm}$ in length, up to $6 \mathrm{~cm}$ wide. Calyx and corolla are widely spreading and twisted. The labellum (lip) has five ridges on the mid lobe and the lateral lobes are erected (Jones, 2006). Usually, it's flowering from February to June. The stem growth is sympodial. The habitat of Dendrobium is distributed from the east coast of the Cape York Peninsula, Queensland as well Singapore, and Indonesia (Clements, 2008). 
Table 1. The morphological comparison features between Phalaenopsis amabilis L and Dendrobium x Superbiens (Iswanto, 2005; Jones, 2006; Sitanggang dan Wagiman, 2007; Rukmana, 2010)

\begin{tabular}{|c|c|c|}
\hline \multirow{2}{*}{ Characteristics } & \multicolumn{2}{|c|}{ Species } \\
\hline & Phalaenopsis amabilis L. & Dendrobium x Superbiens \\
\hline Root type & Sticky roots and aerial roots & Sticky roots \\
\hline pseudobulb & Not present & Present \\
\hline Stem growth & Monopodial & Sympodial \\
\hline Plant height & $10-30 \mathrm{~cm}$ & $30-50 \mathrm{~cm}$ \\
\hline Leaf shape & elliptical, egg-shaped & Oblong \\
\hline Leaf number & 03 to 10 leaves & 5 - 10 leaves \\
\hline leaf length & 15 to $30 \mathrm{~cm}$ & 10 to $18 \mathrm{~cm}$ \\
\hline Leaf width & 8 to $15 \mathrm{~cm}$ & 5 to $6 \mathrm{~cm}$ \\
\hline Leaf color & Dark green & Dark green \\
\hline Flower color & White and composed & Pink and composed \\
\hline Flower stalk length & $10-15 \mathrm{~cm}$ & $10-20 \mathrm{~cm}$ \\
\hline Number of corollas & 3 & 3 \\
\hline Number of calix & 3 & 3 \\
\hline
\end{tabular}

\subsection{Stomatal characteristics}

The stomatal type both in Phalaenopsis amabilis and local orchid Dendrobium $x$ Superbiensshows almost had similar characteristics. The shape of the epidermal cell was in terms of a pentagon, hexagon, and some cells even in irregular shape and only consisted of one cell layer (Fig. 2A and 2B). There was almost no space between the epidermal cells (non irregular spaces), and the nucleus was in the middle of the cell. The stoma is surrounded by four neighboring cells. The two neighboring cells are aligned on each other, on the right side and on the left side of the stoma and the other two neighboring cells are located at each end of the shaft (Rompas et al 2011). While in Dendrobium $x$ Superbienssome stomata were surrounded by neighboring cells in the same position with different shapes among them.

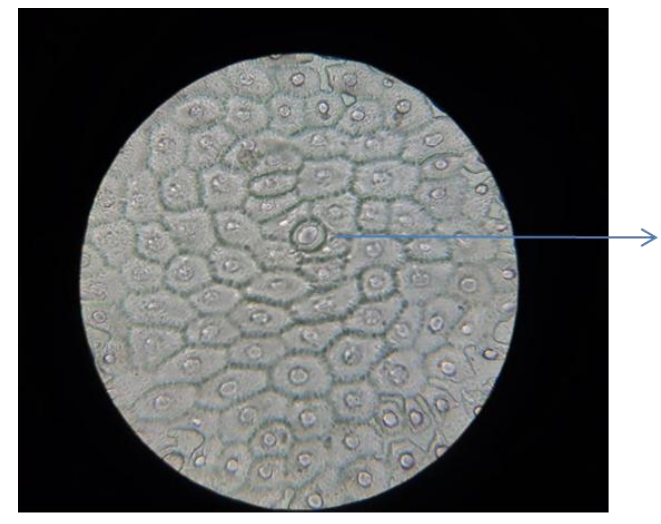

A

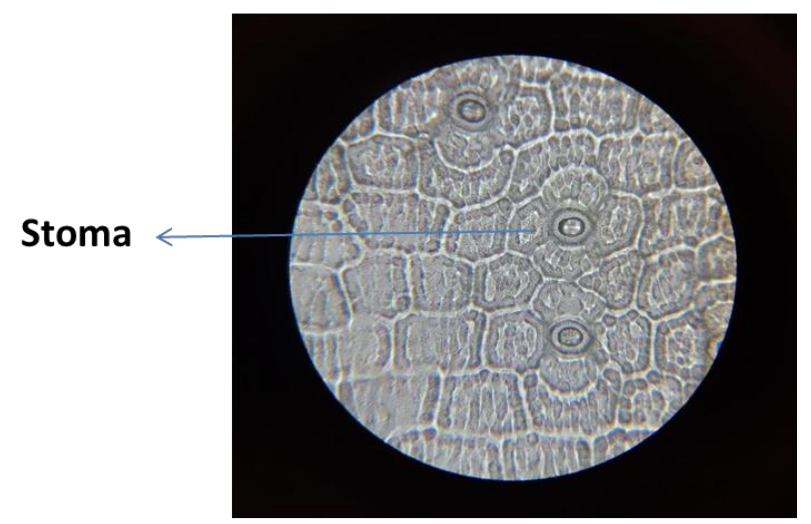

B

Figure 2. The stomatal structure of (A) Phalaenopsis amabilis L. and (B) Dendrobium x Superbiens

The direction of the stomata closing cell is parallel against the neighboring cells. The stomata have kidney-shaped and classified as normocytic type for both in Phalaenopsis amabilis L and Dendrobium $x$ Superbiens as in dicotyledonous plants (Rompas et al, 2011). The observations conducted by Arif and Ratnawati (2018) about anatomical leaf characteristics in some Dendrobium species showed that Dendrobium $x$
Superbienshas the same stomatal type with Dendrobium laxiflorum $\mathrm{L}$, the difference is that Dendrobium Sp has curly pink flower and Dendrobium laxiflorum L. has the curly green yellow flower. Plant taxonomy generally uses the morphological characteristics to determine the species of plant. However, the taxonomist has increased their interest during the science and technology development to find other evidence in plant identification 
such as plant anatomy, which is stomatal characteristics. Some anatomical characteristics can be used including the size of stomata, the shape of the epidermal cell, stomatal type and stomatal density (Grufrin et al. 2011).

Table 2. Stomatal characteristics (Arif and Ratnawati 2018; Rompas et al. 2011)

\begin{tabular}{|c|c|c|c|}
\hline \multirow{2}{*}{ No } & \multirow{2}{*}{ Characteristics } & \multicolumn{2}{|c|}{ Species } \\
\hline & & Phalaenopsis amabilis L. & Dendrobium x Superbiens \\
\hline \multirow[t]{3}{*}{1} & Epidermis & & \\
\hline & Adaxial & Pentagonal, Hexagonal, Ploygonal & Polygonal \\
\hline & Abaxial & Pentagonal, Hexagonal, Ploygonal & Polygonal \\
\hline \multirow[t]{3}{*}{2} & Stomatal Type & & \\
\hline & Adaxial & Anomocytic & Anomocytic \\
\hline & Abaxial & Anomocytic & Anomocytic \\
\hline \multirow[t]{3}{*}{3} & Stomatal density (Average) $\left(\mathrm{mm}^{-2}\right)$ & & \\
\hline & Adaxial & 129.24 & 0 \\
\hline & Abaxial & 100.33 & 290.81 \\
\hline
\end{tabular}

The highest stomatal density (Table 2) was obtained on the abaxial leaf part of Dendrobium x Superbiens $\mathrm{sp}$ $290.81 \mathrm{~mm}^{-2}$ while the lowest frequency was shown on the adaxial of Dendrobium $x$ Superbiens sp $0 \mathrm{~mm}^{-2}$. A research about the strategies of epiphytic orchids for maintaining the water loss mentioned that to adapt with the availability of water, the vascular bundle in epiphytes utilize the morphological and anatomical adaptations in the roots, stems and leaves, including the cuticles thickened, stomata, reduction in surface transpiration through sympodial growth and also development of aerial root systems (Moreira et al, 2013; Yang et al., 2016).

Stomatal density is one stomatal characteristic involved in stomatal conductance and also transpiration rate. The stomatal density of Orchidaceae mostly lower than other angiosperms, therefore this family member can tolerate more severe water deficit than other species with higher stomatal density (Yang et al. 2016). A research conducted in rice obtained that low stomatal density in rice was able to conserve more water, maintain the stomatal conductance and survive drought and high temperature $\left(40^{\circ} \mathrm{C}\right)$ for longer period. Low stomatal density also gave equivalent and improved yield in rice plant, despite reducing the photosynthetic rate in some conditions (Caine et al, 2019)

\section{CONCLUSION}

Phalaenopsis amabilis L and Dendrobium $x$ Superbiens $\mathrm{sp}$ are parts of local orchids that commonly grow and cultivated in Indonesia. Phalaenopsis amabilis L is a monopodial orchid with sticky root and aerial root, which has a different function, thick stem protected by wax, composed flower, the color is white and has been designed as Indonesian national flower. Dendrobium $x$ Superbienshas curly pink flower, the leaf is dark green and one of sympodial orchid. The anomocytic type of stomata observed in both mentioned orchids with four neighboring cells, while the highest stomatal density obtained on the abaxial part of Dendrobium $x$ Superbiensleaf $290.81 \mathrm{~mm}^{-2}$, and the lowest on the adaxial part of Dendrobium $x$ Superbiensleaf $0 \mathrm{~mm}^{-2}$.

\section{ACKNOWLEDGMENT}

The author would like to thank the Department of Biology, Islamic Faculty, University Muhammadiyah Aceh, for providing the laboratory support for the research.

\section{REFERENCES}

Agampodi, V. A., Jayawardena, B. (2009). Effect of coconut water (Cocos nucifera L.) water extract on adventitious root development in vegetative propagation of Dracaena purple compacta L. Acta Physiology Plantarum, 31. Pp 279-284

Arif, A., \& Ratnawati, R. (2018) Hubungan kekerabatan anggrek Dendrobium berdasarkan karakteristik morfologi dan anatomis daun. Jurnal Pendidikan Biologi, Vo. 7 (3) 213-222.

Caine, R. S., Yin, X., Sloan, J., Harrison, et al. (2019). Rice with reduced stomatal density conserve water and has improved drough tolerance under future climate conditions. New Phytologist. 221; 371-384

Clements, M. A., Jones, D. L. (2002). Nomenclatural changes in Dendrobieae (Orchidaceae) 1: The Australian region, The Orcadian, Vol. 13. Pp. 485-497.

Darmawati, I. A. P., Rai, I N., Dwiyani R., Astarina, I. A., (2018). Short communication: The diversity of wild Dendrobium (Orchidaceae) in Central Bali, Indonesia. Biodiversitas. Vol 19 (3): 1110-1116

De, L.C., Rao, A. N., Rajeeva, P. K., Srivastava, M. (2015). Morphological characterization in Dendrobium species. J. Biosci 4(1): 1198-1215

Gandawidjaya, D. Sastrapradja, S. (1980). Plasa nutfah Dendrobium asal Indonesia. Buletin Kebun Raya 4 (4): 113-125

Gufrin, Indrawati, Ningsih R, Suratman, N. M., Isa N. N. M., Poulsen, A. D. (2011). Leaf anatomy and pollen studies of Zingiberaceae in Lambusango wildlife reserve, Buton island Indonesia.

Haryanti, S. (2010). Jumlah dan distribusi stomata pada daun 
beberapa spesies tanaman dikotil dan monokotil, Buletin Anatomi dan Fisiologi, Vol. XVIII (2): pp 21-28

Iswanto. (2005). Petunjuk perawatan anggrek. Agromedia Pustaka. Jakarta.

Joshi, R. (2018). Significance of guard cells in photosynthesis, a mechanism for food production in the form of carbohydrates in plants. International Journal of Creative Research Thoughts. Pp 514-517

Jones. D. L. (2006). Native orchid of Australia including the island territories, Reed New Holland, Sydney.

Kosir, P., Skof, S., Luthar, Z. (2004). Direct shoot regeneration from nodes of Phalaenopsis of Orchids. Acta Agriculturae Slovenica, 83: 233-243

Lestari, L., Nurhidayati, T., Nurfadilah, S. (2013). Pengaruh konsentrasi ZPT 2,4 D dan BAP terhadap pertumbuhan dan perkembangan biji Dendrobium laxiflorum J.J Smith secara in vitro. Jurnal Sains dan Seni Pomits, Vol 2(1) : 2337-3520

Lestari, G. E., (2006). Hubungan antara kerapatan stomata dengan ketahanan kekeringan pada somaklon padi gajahmundur, Towuti, dan IR 64. Biodiversitas, 7(1). Pp. 44-48

Manik, F., Suryantini, R., Husni, H. (2017). The Identification Of The Family of Orchidaceae On Sekendal Village Protected Forest Air Besar Sub-District Landak District. Jurnal Hutan Lestari, Vol. 5(2): 183-191.

Moreira, A. S., Filho, J. P., Isaias, R. M. (2013). Structural adaptations of two sympatic ephiphytic orchids (Orchidaceae) to a cloudy forest environment in rocky outcrops of Southeas Brazil. Rev. Biol Trop. 61(13): 1053-65

Puspitaningtyas, D. M., Mursidawati. (1999). Koleksi anggrek kebun raya bogor. Vol 1 (2): UPT Balai Pengembangan Kebun Raya-LIPI

Robertson, K. R., Downie, S. R., Mason, S. L. (2006). Chapter 4: Botany in Master Naturalist Illionis.

Rompas, Y., Rampe, H. L., Rumondor, M. J. (2011). Struktur sel epidermis dan stomata daun beberapa tumbuhan suku Orchidaceae. Jurnal Bioslogos, Vol 1 (1).

Rukmana, R. (2010). Budidaya anggrek bulan. Yogyakarta. Kanisius

Seminarti, E. (2002). Orchid biotechnology for Indonesian orchids conservation and industry. AIP Conference Proceeding, American Institute of Physics

Sitanggang, M., Wagiman. (2007). Menanam dan membungakan anggrek di pekarangan rumah Agromedia Pustaka. Jakarta

Schuiteman, A., de Vogel, E. F.(2007). Orchidaceae of Papua, in The Ecology of Papua, edited by A. J. Marshal and B. M. Behler, Periplus Publishing Group, Singapore. Pp 435 - 456

Yang, Shi-Jian., Sun, M., Yang, Qiu-Yun., Ma, Ren-Yi., Zhang, Jiao-Lin., Zhang, Shi-Bao. (2016). Two strategies by ephiphytic orchids for maintaining water balance: thick cuticles in leaves and water storage in pseudobulbs. Aob plants.

Yuswanti, H., Dharma, I. P., Utama., Wiraatmaja, I. W. (2015). Mikropropagasi anggrek Phalaenopsis dengan menggunakan eksplan tangkai bunga. AGROTROP. 5(2): 161-166. 
